\title{
THE LINGUISTIC REGISTER OF BRITISH PREPARATORY SCHOOLS IN ANTHONY BUCKERIDGE'S JENNINGS GOES TO SCHOOL
}

\author{
Graeme Davis
}

The unique language employed in many British Public Schools has long been noted; that of the Preparatory Schools from which the Public Schools mostly draw their pupils has generally been neglected. ${ }^{1}$ Public School English is a feature of such popular sources as the novel Tom Brown's Schooldays (1857) and has had formal analysis at least since 1900, the year of publication of Farmer's Public School Word Book. By contrast, there are far fewer sources for the language of the Preparatory Schools. In Jennings Goes to School, novelist Anthony Buckeridge provides a surprisingly rich overview of this English linguistic Register as it was in the late 1940s. The Jennings Register is explored here through a Jennings word-list as an appendix to this article, and through discussion within this article of the Register in action. The Jennings Register looks in two directions. It is the primary source of Public School English and therefore of the dialect of British English associated with the Upper and Upper-Middle Classes. However, the Jennings Register surprises in that its sources are primarily Working Class and from popular culture, and in this respect it is a dialect of the Working Class. Preparatory School English therefore appears to provide a bridge between various classbased dialects of British English. It may be regarded as a linguistic and cultural unifier for Britain in the twentieth century.

English school language should be regarded as a particular Register of English, analogous to workplace Registers. Linguistic concepts of workplace Registers of English developed in the 1980s, through for example Trudgill's observation (1983, p101) that there is a lexically distinct Register in many workplaces and professions. There is a ready transfer to the concept to the language of schools. Within England these school Registers appear to have reached their zenith of distinctiveness in the years immediately following the Second World War, so the time of the Jennings Register. They undoubtedly

\footnotetext{
${ }^{1}$ The structure of British Schools should perhaps be clarified. Public Schools are feecharging schools, in contrast with State Schools which charge no fees. Public Schools include many of the most famous schools in Britain, perhaps in the world, for example Charterhouse, Eton, Harrow, Merchant Taylors', Rugby, St Paul's, Shrewsbury, Westminster and Winchester. Most are boarding schools, most were for boys only, and most provide education for ages 13-18. Fee-charging schools for the age range of (typically) 8-13 are called Preparatory Schools, and these are schools which prepare pupils for entry to the Public Schools.
} 
still exist, though exposure to mass media has reduced somewhat their distinctiveness.

Much of the interest in school Register has tended to focus on the lexis of specific Public Schools and particular activities at those schools. Thus, for example the Eton Wall Game, a sport unique to Eton College, is played on a pitch called "The Furrow" and with a scoring area called "caix", while a scrum is a "bully". These words are unique to this single school and to a unique game at this school. In contrast with such single-school specific lexis, there is a lexis common to all Public Schools, which derives from the schools from which they recruit most of their pupils, the Preparatory Schools. This is the source of most of the common lexis and form of expression of the Public Schools, and ultimately a source of British middle-class English.

\section{THE JENNINGS REGISTER}

Jennings Goes to School, first published in 1950, is the first of two-dozen novels about the exploits of eleven-year old schoolboy Jennings. It was preceded by a radio short story "Jennings Learns the Ropes", broadcast in 1948, and which forms the first chapter of the novel; subsequent novels in the series, published until 1977, tend to present less of the school Register, as Buckeridge sought a broader readership. Of the series, it is Jennings Goes to School which is particularly useful for its material on the school idiom, and which is the source for this article.

References within the novel makes it clear that it is set in the post-war years, and the first novel can therefore be placed firmly in the late 1940s. This is the time when Buckeridge was a teacher at a Preparatory School in Ramsgate, Kent, and this appears to be where he is observing the language of a Preparatory School. Buckeridge's fictitious school in Jennings Goes to School is named as "Linbury Court Preparatory School" and, in terms of its buildings and fields, is based on the school he himself attended as a child, Seaford College in Sussex. Linbury is a fictitious place, but Buckeridge imagines his Linbury Court to be in much the location of Seaford College, as indicated by references to the sea, the South Downs, Brighton, and to Haywards Heath "fifteen miles away". The children of Linbury Court include both day-boys and boarders; while the boarders can in theory be from anywhere (Hertfordshire and France are mentioned), most are from the vicinity. Buckeridge in Jennings Goes to School therefore presents a SouthEast England Preparatory School with children from South-East England; he blends the preparatory school he knew in the 1920s with the child language he observed in a preparatory school in the late 1940s.

Buckeridge's Linbury Court is typical of English Preparatory Schools of the day. It has a traditional syllabus which prioritises Latin, at that time still the mainstay of Public School education and a requirement for entry to British universities. It is wholly appropriate that Linbury Court should have a 
Classical scholar as its headmaster. The syllabus includes mathematics, English, history, geography, French and music; there is scant mention of teaching science and technology, while art and drama appear relegated to extra-curricular activities. Religion appears as part of the school assembly but not as a subject taught as an academic discipline.

Buckeridge is therefore presenting a group of children defined by location (South-East England), date (late 1940s) and class (upper-middle) and situating them within a particular educational culture. His presentation of the dialogue of his school children has been noted by commentators as being rich and creative. This is the dialect of such comic forms as "crystalised cheesecakes" and "fossilised fish-hooks". However there's far more than comedy in Buckeridge's lexis. In effect, he presents a corpus for a specific school-based dialect, with sufficient quantity to permit useful analysis.

While Preparatory Schools still flourish in Britain, their character today is very different from those of the world of Jennings. Buckeridge presents material for something that no longer exists.

\section{ACCENT}

The accent of the Preparatory Schools is a form of RP (Received Pronunciation), the accent that was, in the 1950s, that of the Public Schools, of Oxford and Cambridge, and of the BBC. It is the accent of the privileged classes. This accent overlaps with the regional accents of SE England, the location in which Buckeridge sets his school. There are very few direct references to accent in any of the Jennings novels, perhaps indicating that the speakers were unconscious of using an accent. The people from outside the school encountered by Jennings and his classmates would have been speaking in a broadly similar regional accent.

\section{Language Mistakes}

In looking at the Jennings lexis it is important to exclude what are simply language mistakes made by children. Their lexis is muddled, so "illiterate" and "illegible" are simply confused. "Congruent triangles" become "incongruous triangles", a "taxidermist" becomes a "taximeter". The children's syntax is frequently clumsy. For example, poor syntax rather than the specific syntax of a Register can be found in "It's a jolly wizard job I'm not a chap at home I know at home's uncle, because he's always ill on boats, isn't it, sir?" While with persistence a meaning can be found in this, the double subordination is certainly not good practice. The struggle for the right word is clear as the children look for the word "tarantula": "Ta-ran-ta-ra... Tarantelle... No that's a dance... Tarradiddle". The children can also misunderstand words they hear. Surprisingly (in an age of open fires) they don't know the word "kindling", believing it is something for young relatives "you know, kith and kin... like duckling and gosling". There are also terms used without much understanding, though in this case correctly: 
- I call Jennings the doughty pivot of the team.

- What's a doughty pivot?

- I'm not sure... but I got it out of a newspaper.

There can also be a misappropriation of terms. "Old codger" is an established term for an eccentric, old man, and implies mild derision, but is applied by Buckeridge to Paul Revere, in a way that must horrify most American readers.

The dialogue contains numerous examples of language errors which are humorous, though Buckeridge presents them as simple mistakes. For example there is the (understandable) confusion of a literal "portfolio" (brief-case) and the job title "Minister without Portfolio" (a UK government minister without specific responsibilities), so "the Silent Shadow was hiding in a corner with the portfolio belonging to the Minister without Portfolio on a table in front of him"

Adult responses to such mistakes are inconsistent. Parents and care-givers generally prioritise accuracy (and truthfulness) of content over the language form. There is often accommodation of the linguistic eccentricities of children. Indeed Jennings' parents parrot his expressions "ozard oik" and "bogus ruin", and are clearly amused by them. By contrast the school masters prioritise linguistic accuracy, seemingly placing it above content in importance. The rules of prescriptive English grammar are prioritised. The question "who do I have to write to, sir?" is corrected to "whom", with as much emphasis placed on the grammatical correction as on answering the question. This breaches the tendency of adults to avoid direct correction of a child's language. When the question is answered it is with the sentence "To your mother and father, of course, who else?" making precisely the grammar mistake that has just been corrected.

Within the world of the Preparatory School, the language of the children sometimes seems preferable to that of the adults. An instruction for use of the fire escape harness is reported as "He disengages the clasp governing the fastenings of the harness and remains on terra firma", and this is the language that the children are told is correct and encouraged to use. It is paraphrased by one of the children as "you mean he slides out of the sling", which seems better at expressing the meaning, but within the world of the school is regarded as something akin to a mistake.

\section{OVERT DISCUSSION ON LANGUAGE}

"The Wizard of Oz" has acknowledged impact on the children's language. The source is not the original novel or early films but specifically the 1939 film, which was a staple of British war-time and post-war cinema, and which 
was re-released in 1949, the year before Jennings Goes to School was published. From this source "Wizard" means simply good, referencing what the wizard of the film is believed to be through most of the story, rather than the flawed character revealed towards the end. A created word is "ozard", perceived as an antonym of "wizard" and meaning bad.

- He's as ozard as a coot.

- You can only be bald as a coot. It's a simile.

- As ozard as a buzzard.

\section{NOMENCLATURE}

The masters are addressed as "sir". The third person address is the teacher's title and name (or a nickname when the teacher is not present) though "sir" is frequently (and wrongly) used as "sir's pardon". The pupils are all addressed by their surnames, both by the school masters and by one another. Between themselves they sometimes use short-forms. In addition, there are nicknames.

Many school masters and workers are known by the boys as a nickname preceded by "old", as Old Wilkie (Mr Wilkins) and the day and night servants Old Pyjams (Mr Robinson) and Old Nightie (Mr Hawkins). Later novels demonstrate that "Old Wilkie" is a young man, and there's no reason to think "Old Pyjams" and "Old Nightie" are elderly. Rather, this appears to be the Southern regional dialect use of "old" as a qualifier meaning something that is familiar or well-known.

Conscious construction of a nickname is set out to explain "Bod": "His name's Temple, and his initials are C.A.T., so naturally we call him Dog... It's a bit of a sweat calling him Dog so we call him Dogsbody for short... Bod short for Dogsbody." The stages are clearly set out:

- Start with the initials read as a word.

- Select a word with which it is frequently paired.

- Lengthen to a multi-syllabic word.

- Omit the stem.

The complexity of the process invites comment. A parallel process may be found in London's Cockney Rhyming Slang, and the process is so unusual that the parallel can hardly be accidental:

- Start with a nickname (copper for policeman, from a policeman's helmet's copper badge).

- Select a rhyming word (stopper).

- Lengthen to a set phrase (bottle and stopper). 
- Omit the rhyming word to leave bottle.

Thus, "bottle" is (or was; I doubt it is still used) Cockney Rhyming Slang for a policeman.

The language play which has created the nickname "Bod" may be regarded as a creative form which appears to draw its inspiration from Cockney Rhyming Slang. The children of Linbury Court were certainly not speaking Cockney Rhyming Slang, and nor were their upper-middle class parents, but such was the twentieth century fluidity of the class system that it is entirely possible that their grandparents were. Cockney Rhyming Slang probably originated as early as the 1840s (as a contrived argot to exclude the outsider) but reached its peak in the late nineteenth century and the years up to the outbreak of the First World War. It was still to be found in the 1940s, and has survived in a diminished form subsequently.

The children's' own views on naming can be seen as Jennings and Darbishire debate at length the name that should be given to the hero of the detective story they are writing. Their first idea is "Mr Nehemiah Bultitude", a name which is "out of the ordinary", then "Mr Theophilus Goodbody", a name they reject because he "would have to be a clergyman". These first names and surnames certainly exist in the English name-stock (though they are unusual), so Buckeridge's children are at this stage working with the building blocks of English onomastics. They set out an idea of fictional naming practice in the terms: "if he's a schoolmaster he's Dr Whackem or something like that", and they themselves make a parallel with Charles Dickens, who produced such names such as Pecksniff, Cheeryble and Cruncher. Further discussion departs from the real onomastic building blocks of British naming practice, and creates the example "Marlinspike Mainbrace" with the observation "You've just got to be a sailor, even if you don't want to be". This name is wholly invented as neither part is in the English namestock. Curiously the children go on to look at the syllable structure of names of detectives, including Sherlock Holmes, and conclude that a detective should have a two-syllable first name and one-syllable second name. In this they have stumbled upon the observation that single-syllable surnames in English are most often paired with a multi-syllable first name, else the name may sound harsh or common. The children decide "unless your surname consisted of a single syllable and your parents had been generous enough to give you a two-syllabled first name, you could never hope to succeed in the world of crime detection", and with this syllable structure in mind they first look at "Egbert Snope", which they dismiss on the grounds that it "doesn't sound right". However the suggestion "Flixton Slick" (a wholly made-up name) is received with the comment "Wizard prang!" The appeal seems to be its assonance. This is augmented with alliteration in the phrase "Flixton Slick - Super Sleuth". Buckeridge's children's language play is successful; this really is a name that works. 


\section{INTENSIFIERS}

The area of child vocabulary around intensifiers and expressions of approval may be described as "that long list of words boys and girls use for a while to express high commendation and then get tired of, such as, to go no further back than the present century, topping, spiffing, ripping, wizard, posh, smashing" (Gower, 1965). Some expressions defy explanation. Jennings, on being selected for the football team, exclaims "Oh, hefty ziggerty door knobs!" Somewhat simpler is "Super-duper, smashing priority prang". There are also forms which are invented as part of language play: "Witch Prang... It's the feminine of Wizard Prang. Witch Prang is Wizard Prang's wife".

\section{LATIN}

Jennings and his contemporaries are the last generation of English school children to have an education so centred on Latin. Their meals begin with the grace "benedictus, benedicat" and end with "benedicto, benedicata", so "may the Blessed give a blessing" and "let the Blessed be blessed" (assuming of course that "benedicata" is a dative; there is an argument that "benedicata" is an ablative, and Jennings' teachers might well have expected him to know this). The grace prompts the nickname Benedick for the master who habitually says it, and whose name is Mr Carter. This short Grace was (and in a few cases still is) said at many English Public Schools and Universities. Latin teaching appears to include the whole of Latin grammar. The children's Latin lessons include for example the passive conjugation of the verb audio (audior, audiris, auditor, audimur, audimini, audiuntur) suggesting that the school is determined to send them to public school with a thorough knowledge of Latin grammar. A schoolboy auction for unwanted personal property is conducted with the Latinate language:

- Quis for a piece of junk!

- Ego!

When struggling to identify a spider and speculating that it may be a tarantula, the information that strikes them as important is its declension class, so "it goes like mensa. Tarantula - tarantula - tarantulam - tarantulae tarantula". Where two brothers attend the school, they are distinguished by Latin tags after their surname, so "Brown major" and "Brown minor". The headmaster, as a Classical scholar, has a particularly Latinate mindset. When he asks the inattentive Jennings if he is hibernating, the response from Jennings is "I don't know what hiber - what you said - means, sir" prompting the complex explanation that it is "... derived from the Latin word hiberna meaning winter". Classical mythology is referenced. For example, the 
headmaster instructs a pupil to carry a message: "Explain that Mr Wilkins is suspended, like the sword of Damocles, on an obstinate tendril of ivy", a message which confuses both pupil and recipient.

It is in the Latin that the Preparatory School Register may be regarded as most obviously distinct from Working Class dialects. Buckeridge appears to have recognised this, and did remove the Latin from later editions of Jennings Goes to School, presumably recognising that it was fast becoming incomprehensible to most child readers.

\section{CLASS}

The Jennings lexicon does contain items which are associated with the middle or upper class. Anything from Latin is surely within this category, so terms including "cave", "quis" and "ego". The term "chap" used by Jennings was once class-specific in English (as middle class), contrasting with working-class "bloke" and "geezer"; the American import "guy" has tended to replace all these as a term which is not class-specific.

Perhaps surprisingly, much of the vocabulary comes from the lower classes of British society. The Jennings lexicon includes such terms as "smashing" (from the language of Irish navvies), "cove" (from thieves' cant) and makes use of the formation strategies of London's Cockney Rhyming Slang, producing the name "Bod" and terms such as "bazooka" and "bish" which would be at home within this Register. The slang of two world wars is reflected. "Muck" is a First World War term, but one originally associated with the (mostly working class) privates in the trenches of the Western Front. "Prang" and "spiv" are from the Second World War, and similarly workingclass in origin.

\section{FINAL}

Buckeridge records in Jennings Goes to School a Register which is not of the Upper-Middle class, and which is distinct from the Public School English of at least some prestigious schools. Rather it is a socially-unifying Register of English. This is the world of the Britain that has experienced the Second World War and the class encounters that this created, and which is in transition to a new social order. His children are speaking a Register which is part of the emerging post-war society. Buckeridge later takes his representation of school Register one step further in his 1950s "Rex Milligan" series, set not in a private Preparatory School but a state Grammar School. Buckeridge's use of language presents a Register which reflects the reality of an emerging British social cohesion. This is the language of a new Britain. 


\section{JENNINGS' LEXIS FROM JENNINGS GOES TO SCHOOL}

bate

in a in a temper. This is a shortened form of debate, used in the now obsolete sense of contention or argument.

Bazooka a term of abuse. A bazooka is a shoulder-held gun used to shoot missiles. Here it is probably a rhyming word for verruca.

bish mistake. The origin is obscure. Oxford English Dictionary suggests a variant of bikh, a Nepalese plant poison. It may be a rhyming word based on mishmash, a confused mixture.

brain clever person.

breezy angry. This meaning contrasts with the usual figurative meaning cheerful. It appears to be a specific figurative use of the school Register.

bucolic plague a malapropism for bubonic plague.

by jet-propulsion by being thrown. The appeal is to novelty. The first jet-propelled plane to enter service in the UK was the Gloster Meteor in 1944.

cad

dishonourable person. While an established word in the English lexicon, it was (and remains) uncommon, and usually has a specific meaning, that of a man whose conduct towards a woman is dishonourable. The meaning has been broadened here.

cave look out! From Latin cave, beware.

chap boy. There may be an unconscious class prejudice. In contemporary English there is a class association of chap as a person of the middle class.

characters people.

coo an exclamation of pleasure of surprise, and perhaps a swearword substitute. The form is probably archaic today.

cove

decent friend. This is from British thieves' cant.

dirty slacker a term of abuse.

fagged out tired out. A fag is a pupil who runs errands for an older pupil or prefect; fagged out is tired out from too many such errands.

foxed stole. The quality of a fox is not obvious in this concept.

foxed out crept out, was absent from school without leave. The form references the craftiness of the fox.

frantic jam a predicament which is acute. Frantic appears to preserve its original meaning of frenzy and madness.

funked avoided something through fear; chickened out. This is widespread British slang, now becoming archaic. A funk is a coward. 
getting uppish getting above his station, self-assertive. There is a social class reference in the word.

go and boil yourself go away, get lost. This is a variant of "go and boil your head". In the British Isles it is most commonly encountered in Scotland. Jennings also uses "go and chase yourself'.

good heavens a swear word substitute.

good old Jen reliable Jennings. The meaning is literal, as opposed to the modern usage which is frequently ironical. ("Good old Smith, he always gets it wrong.")

goof fool. This is more common in American slang than British slang. Its use in Jennings may well be influenced by the Disney character Goofy.

gosh a swear word substitute.

hairy an intensifier in the phrase "hairy strength". However, "hairy ruin" is a set phrase for a person who is foolish or slow on the uptake. "Hairy" may have developed from the archaic adjectival sense of frightening, and have some pejorative quality.

hefty an intensifier, so "hefty bate", "hefty daring", "hefty poisonous", "hefty spivish".

hoof off not understood by a teacher and defined (very formally) by a pupil as "take our departure". It is a long-established term in British slang. Presumably the teacher was feigning noncomprehension of a slang term.

jolly an intensifier, in "jolly well going to try" and "jolly wizard".

muck food. In origin this is British First World War slang. A "muck in" was an informal meal of shared food. Variants are "supersonic muck" and "super-wizard muck".

Mud as, his name was Mud. A stupid person who is ostracised. This is a long-established British English slang term.

oh, golly; oh, gosh; oh, prang alternatives to swear words.

oik member of the lower class, particularly someone who is rude. An intensified form is "ruinous oik". "Bogus oik" is a nasty person; "bogus" appears to be used in the sense harmful.

ozard Bad. This neologism is further developed as "ozard squared" and "ozard cubed" for degrees of badness, while "ozard egg" is a bad person and "ozard hoo-hah" a bad confrontation.

ozard as a coot extremely bad. The phrase is a parallel construction to the familiar "bald as a coot". However, here "coot" may mean not the bird but the (now archaic) use of coot for an eccentric, old man.

prang a result or an idea that has occurred. The word entered the language as Second World War RAF slang as a verb meaning 
to damage slightly an aircraft or ground vehicle, and extended to the noun for the dent or scratch caused. Jennings slang shows a further transformation. A "prang idea" is a breakthrough idea. "Super prang nerve" is an idea that is very brave.

Putrid very bad

putridly funny very funny; a bad joke which is nonetheless funny.

radio-active worst, something to keep clear of. Radioactive became part of the popular lexicon

following the atom bombs on

Hiroshima and Nagasaki. Buckeridge hyphenates, suggesting a lack of familiarity with the term.

shift to move quickly

sissy a term of abuse; a cry baby. The Jennings use appears to be only moderately pejorative.

smashing a positive intensifier, as "smashing decent" and "smashing rare". Well-established in British English, probably from Irish "is maith sin", "it is good", and therefore an Irish navvy expression which has entered English. Also found as "smashon".

spiv a spiv is a British Second World War term for a black marketer. The term can imply both condemnation of the criminality and gratitude for provision of goods wanted. The pejorative sense is in Jennings is "spivish disloyal" and "spivish ozard" while the euphemistic is "spivish rare". The set phrase "wear your cap like a spiv" is to wear a cap backwards. Spivs used rakish dress to identify themselves.

stale buns old news

super an intensifies, as "super-delectable", "super-duper" "superscrewy squared".

Supersonic while there are reports of breaking the sound barrier during the Second World War the first uncontested record is 1947.

supersonic ear-sight excellent hearing

swank to boast. The origin is to show off class or wealth, to appear posh.

swizzle a bad disappointment or con. This is British school slang from at least the late nineteenth century. Also found as "rotten swizzle".

to stick up for to support a sports team; to be a fan.

tuck food, particularly the children's own food.

wizard good 


\section{REFERENCES}

Farmer, John S., 1900, Public School Word Book, Hirschfield Brothers, London

Gower, Ernest, 1965, Fowler's Modern English Usage, OUP.

Halliday, Michael A.K., 1989, Spoken and Written Language, OUP.

Janes, Michael, 2007, Playground Slang and Teenspeak, Abson Books, London.

Marples, Morris, 1940, Public School Slang, Constable and Company, London.

Trudgill, Peter, 1983, Sociolinguistics: an Introduction to Language and Society, Penguin Books, London. 